\title{
Azospirillum brasilense INOCULATION AND MANAGEMENT OF FERTILIZER NITROGEN IN MAIZE
}

\author{
Roberta Pacola Oliveira ${ }^{1}$, Sebastião Ferreira Lima ${ }^{1}$, Rita de Cássia Felix Alvarez ${ }^{1}$, Vera Lucia Divan \\ Baldani $^{2}$, Marcela Pacola Oliveira ${ }^{3}$, Marivaine Silva Brasil ${ }^{4}$
}

\author{
${ }^{1}$ Universidade Federal de Mato Grosso do Sul - Chapadão do Sul. E-mail: robertapacola@hotmail.com; \\ sebastiao.lima@ufms.br; rita.alvarez@ufms.br \\ 2EMBRAPA. E-mail: vera.baldani@embrapa.br \\ ${ }^{3}$ Universidade Estadual Paulista - Ilha Solteira. E-mail: marcela_pacola@hotmail.com \\ ${ }^{4}$ Universidade Federal de Mato Grosso do Sul - Campus Pantanal. E-mail: marivaine.brasil@ufms.br
}

\section{ABSTRACT}

The objective of this study was to evaluate the Azospirillum brasilense effect associated with the nitrogen fertilization and inoculation systems in maize. Treatments sown in season and off-season were distributed in randomized blocks with factorial arrangement $2 \times 2 \times 2+1$, with the strains Abv5 + Abv6 (commercial inoculant) and MAY1, inoculating the seed and in the groove, presence and absence of nitrogen fertilization + control. The following evaluations were carried out in the season and the offseason sowing: number of grains per ear, total number of ears, grain mass per ear, mass of 100 grains, nitrogen content in grains and productivity. In season, the number of grains per ear with Abv5 + Abv6 and MAY1 were 42 and $40 \%$ higher, respectively, compared to the control. The highest number of ears with Abv5 + Abv6 was 57037 and 48148, respectively, for seed application, without $\mathrm{N}$ and application in the groove, with N. With use of MAY1 were obtained 53333 and 50370 ears ha $^{-1}$, respectively, for the application in the seed, without and with $\mathrm{N}$. The highest mass of grain per ear (185 g) was obtained by application of MAY1 in the groove, with N. In off-season, the treatment with MAY1 in the seed, without $\mathrm{N}$, presented the highest number of grains per ear, reaching 634 units. The use of the MAY1 strain inoculated in the seed, with the use of $\mathrm{N}$, resulted in an increase in grain yield of maize harvests reaching $6819 \mathrm{~kg} \mathrm{ha}^{-1}$. Both Abv5 + Abv6 strain did not result in increased maize grain yield, reaching an average of $5682 \mathrm{~kg} \mathrm{ha}^{-1}$. In addition, the use of any strain studied did not result in increased of maize grain yield when submitted to groove application, obtaining on average $5648 \mathrm{~kg} \mathrm{ha}^{-1}$.

Keywords: Biological fixation nitrogen, diazotrophic bacteria, Zea mays 


\section{INOCULAÇÃO DE Azospirillum brasilense E MANEJO DA ADUBAÇÃO NITROGENADA NA CULTURA DO MILHO}

\section{RESUMO}

O objetivo deste trabalho foi avaliar o efeito de Azospirillum brasilense associado à adubação nitrogenada e sistemas de inoculação na cultura do milho. Os tratamentos, semeados em safra e safrinha, foram distribuídos em blocos ao acaso com arranjo fatorial 2x2x2 + 1, com as estirpes Abv5 + Abv6 (inoculante comercial) e MAY1, inoculação na semente e no sulco, presença e ausência de adubação nitrogenada + testemunha. Foram realizadas as seguintes avaliações em semeadura de safra e safrinha: número de grãos por espiga, número total de espigas, massa de grãos por espiga, massa de 100 grãos, teor de nitrogênio nos grãos e produtividade. Na safra, o número de grãos por espiga com Abv5 + Abv6 e MAY1 foram 42 e $40 \%$ maiores, respectivamente, comparados ao controle. O maior número de espigas com Abv5 + Abv6 foi de 57037 e 48148, respectivamente, para a aplicação na semente, sem N e aplicação no sulco com N. Com uso de MAY1 foram obtidas 53333 e 50370 espigas ha $^{-1}$, respectivamente, para a aplicação na semente, sem e com N. A maior massa de grãos por espiga (185 g) foi obtida com aplicação de MAY1 no sulco, com N. Em safrinha, o tratamento com MAY1 na semente, sem N, apresentou maior número de grãos por espiga, chegando a 634 unidades. A utilização da estirpe MAY1 inoculada na semente, com uso de $\mathrm{N}$, proporcionou aumento na produtividade de grãos de milho safra, atingindo $6819 \mathrm{~kg} \mathrm{ha}^{-1}$. O uso das estirpes Abv5 + Abv6 não resultou em aumento da produtividade de grãos de milho, atingindo na média $5682 \mathrm{~kg} \mathrm{ha}^{-1}$. Também o uso de qualquer estirpe estudada não resultou em aumento de produtividade de grão de milho quando aplicado via sulco, obtendo na média $5648 \mathrm{~kg} \mathrm{ha}^{-1}$.

Palavras-chave: Fixação biológica nitrogênio, bactérias diazotróficas, Zea mays

\section{INTRODUCTION}

Brazil occupies the third position in the world ranking of maize production, behind USA and China, reach a cultivated area of 17.6 million hectares on the harvest 2016/2017 (USDA, 2017). Consider the production sum of the first and second harvest Brazil has reached 97.8 million tons, with a mean productivity of $5.6 \mathrm{t} \mathrm{ha}^{-1}$ for both harvest (CONAB, 2018). The maize sowing is conducted twice during the year, while that in the center-west region of Brazil, the first harvest is sown between November and 
December and the second one from January to April, generally after the early-season soybean (CRUZ et al., 2010).

The frequent occurrence of dry periods in the cerrado region (MARTINS et al., 2015), reaching especially the maize second harvest sown, can reduce the transpiration rate of this plants, resulting in lower N absorption and others nutrients. Furthermore, according to Saikia and Jain (2007), the tropical regions soils are poor in $\mathrm{N}$ and the fertilization harnessing stays around $50 \%$ only, allies to high costs, has directed the research to natural fixation. For high yields of corn grains, the costs of this nutrient are high, depending on the amount required by the crop. Farinelli and Lemos (2012) obtained maximum yields of corn grain with dose of $151 \mathrm{~kg} \mathrm{ha}^{-1}$ of $\mathrm{N}$.

In this way, the plant growth promoting bacteria use can build a strategy capable to improve the obtaining of $\mathrm{N}$ in the fertilizers and reduce the environmental risks due fertilization (OWEN et al, 2015; HERRERA et al., 2016). These bacteria are able to realize activities like the biological fixation of nitrogen (BFN), enhancement of the adventitious roots growing, and the increase of the activity of reductase of the nitrate (CASSÁN et al., 2008).

Among the species of microorganisms that realize the nitrogen fixation on the grasses roots, the Azospirillum brasilense bacteria is the most studied for inoculation of grasses in the field, with success (FERREIRA et al, 2013; HUNGRIA et al, 2016) and is being recommended by many researchers in Brazil (HUNGRIA, 2011; ARAÚJO et al., 2014; QUADROS et al., 2014). These microorganisms possess free life, with high competitiveness in the colonization period, using $\mathrm{N}$, ammonia, nitrate, nitrite, amino acids and molecular nitrogen as source.

The use of inoculants based on Azospirillum brasilense on the maize culture still facing obstacles due to the inconsistency of the researches results, that may vary according to some factors like the utilized cultivar, soil and climate conditions, methods and conditions of the field experiments, among others (FIORI et al, 2010).

Thus, the objective of this work was to evaluate the effects of Azospirillum brasilense associated to the nitrogen fertilization and inoculation systems on the maize culture.

\section{MATERIAL AND METHODS}

The experiments were conducted in the agricultural year of 2014/2015 during the season and offseason period, at the municipality of Chapadão do Sul, in the state of Mato Grosso do Sul, Brazil, in experimental area of the Federal University of Mato Grosso do Sul situated at $18^{\circ} 46^{\prime} 17,8^{\prime}$ latitude 
south, $52^{\circ} 37^{\prime} 27,7^{\prime \prime}$ longitude west and altitude of $813 \mathrm{~m}$. The climate of the region is classified as humid tropical with dry winter and rainy summer, mean temperature varying between $13^{\circ} \mathrm{C}$ and $28^{\circ} \mathrm{C}$ and annual mean precipitation of $1.850 \mathrm{~mm}$ (CUNHA et al., 2013). During the conduction of the experiment the data of rainfall and temperature of the place were obtained (Figure 1).

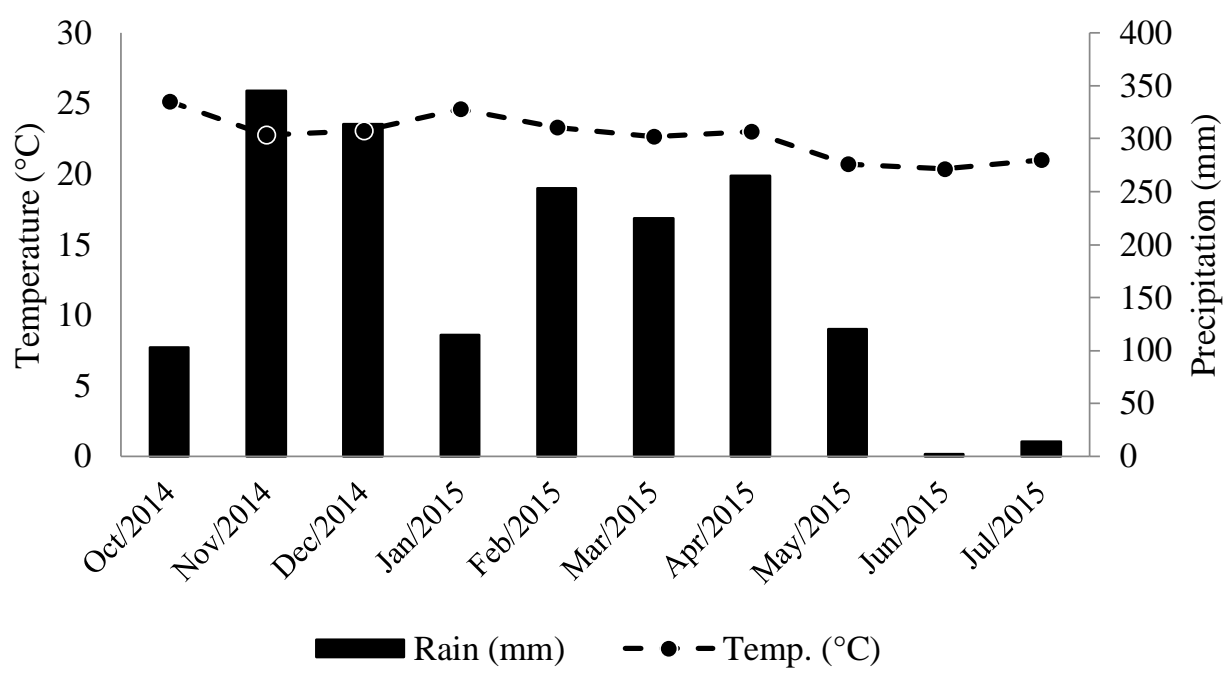

Figure 1. Precipitation and average temperature during the experiment. Chapadão do Sul, 2014/15

The soil of the experimental area is classified as dystrophic Red Latosol, with clayey texture, according to the Brazilian system of soil classification (SANTOS et al., 2013). The chemical analysis of the layer of 0,00-0,20 m corresponds to the following values: $\mathrm{pH}: 4,7$ in $\mathrm{CaCl}_{2}$; $\mathrm{MO}: 29,5 \mathrm{~g} \mathrm{dm}^{-3} ; \mathrm{P}: 11$, $6 \mathrm{mg} \mathrm{dm}{ }^{-3}$; K: 0,26 $\mathrm{cmol}_{\mathrm{c}} \mathrm{dm}^{-3}$; Ca: 2,3 $\mathrm{cmol}_{\mathrm{c}} \mathrm{dm}^{-3} ; \mathrm{Mg}: 0,5 \mathrm{cmol}_{\mathrm{c}} \mathrm{dm}^{-3}$; CTC: 8,4 $\mathrm{cmol}_{\mathrm{c}} \mathrm{dm}^{-3}$; and V: $36,6 \%$. for raise the base saturation to $50 \%$ the liming was conducted, according to Souza e Lobato (2004) recommendations. The season and off-season sowing was conducted by manual form, the season being conducted on November $21^{\text {st }}, 2014$ and the off-season on February $27^{\text {th }}, 2015$. The application of $\mathrm{P}$ and $\mathrm{K}$ in the base followed the recommendations of Souza and Lobato (2004), with $100 \mathrm{~kg} \mathrm{P}_{2} \mathrm{O}_{5} \mathrm{ha}^{-1}$ and 50 $\mathrm{kg} \mathrm{K}_{2} \mathrm{O} \mathrm{ha}^{-1}$ for sowing in the season and $80 \mathrm{~kg} \mathrm{P}_{2} \mathrm{O}_{5} \mathrm{ha}^{-1}$ and $40 \mathrm{~kg} \mathrm{~K}_{2} \mathrm{O} \mathrm{ha}{ }^{-1}$ for the sowing in the offseason.

The experimental plot adopted was with random blocks, with three repetitions, in factorial scheme $2 \times 2 \times 2+1$ (additional control treatment), the treatments being constituted by combinations of absence and presence of nitrogen fertilization, two strains of growth promoting bacteria and their application in seeds inoculation and groove pulverization. 
The $\mathrm{N}$ dosage for maize culture was $200 \mathrm{~kg} \mathrm{ha}^{-1}$ of $\mathrm{N}$ on total, being applied $20 \mathrm{~kg} \mathrm{ha}^{-1}$ of $\mathrm{N}$ on sowing and $180 \mathrm{~kg} \mathrm{ha}^{-1}$ of $\mathrm{N}$ on the cover (season period) and $70 \mathrm{~kg} \mathrm{ha}^{-1}$ of total $\mathrm{N}$ being $10 \mathrm{~kg} \mathrm{ha}^{-1}$ of $\mathrm{N}$ applied on sowing and $60 \mathrm{~kg} \mathrm{ha}^{-1}$ of $\mathrm{N}$ on cover (off-season period). The $\mathrm{N}$ doses used were based on the de Souza e Lobato (2004) recommendations, considering the grain yield expectations for each cultivation period.

The growth promoter bacteria were obtained by the commercial inoculant Masterfix containing the bacteria of the species Azospirillum brasilense, strains Abv5 and Abv6 (with 2x10 cells/mL) and inoculant containing the bacteria of the species A. brasiliense, strain MAY1 (with $2 \times 10^{8}$ cells $/ \mathrm{mL}$ ) isolated from the grass Hymenachene amplexicaulis which grows naturally on the sub-region of Nhecolândia Pantanal Sul Mato-grossense (SOUZA et al., 2017). This strain was used for presenting high production of indol acetic acid in vitro $(1038,61 \mu \mathrm{M})$. The strain isolation was carried out in the Microbiology and Molecular Biology laboratory in the Mato Grosso do Sul Federal University, campus of Pantanal.

The combination of the three factors studied and the control in additional treatment resulted in nine treatments for season: 1) $100 \mathrm{~mL} \mathrm{ha}^{-1}$ of commercial A. brasilense + inoculation on seed; 2) $300 \mathrm{~mL}$ $\mathrm{ha}^{-1}$ of commercial A. brasilense + groove pulverization; 3) $100 \mathrm{~mL} \mathrm{ha}^{-1}$ of A. brasilense MAY1 + inoculation on seed; 4) $300 \mathrm{~mL} \mathrm{ha}^{-1}$ of $A$. brasilense MAY1 + pulverization on groove; 5) $20 \mathrm{~kg} \mathrm{ha}^{-1}$ of $\mathrm{N}$ on sowing $+180 \mathrm{~kg} \mathrm{ha}^{-1}$ of $\mathrm{N}$ on cover $+100 \mathrm{~mL} \mathrm{ha}^{-1}$ of commercial A. brasilense + inoculation on seed; 6) $20 \mathrm{~kg} \mathrm{ha}^{-1}$ of $\mathrm{N}$ on sowing $+180 \mathrm{~kg} \mathrm{ha}^{-1}$ of $\mathrm{N}$ on cover $+300 \mathrm{~mL} \mathrm{ha}^{-1}$ of commercial A. brasilense + pulverization on groove; 7) $20 \mathrm{~kg} \mathrm{ha}^{-1}$ of $\mathrm{N}$ on sowing $+180 \mathrm{~kg} \mathrm{ha}^{-1}$ of $\mathrm{N}$ on cover $+100 \mathrm{~mL} \mathrm{ha}^{-1}$ of $A$. brasilense MAY1 + inoculation on seed; 8) $20 \mathrm{~kg} \mathrm{ha}^{-1}$ of $\mathrm{N}$ on sowing $+180 \mathrm{~kg} \mathrm{ha}^{-1}$ of $\mathrm{N}$ on cover +300 $\mathrm{mL} \mathrm{ha}^{-1}$ of $A$. brasilense MAY1, pulverization on groove; 9) Control.

For the off-season period, there was kept the same conditions of the treatments, however with the nitrogen fertilization on the dosage of $70 \mathrm{~kg} \mathrm{ha}^{-1}$ of total $\mathrm{N}$ distributed in $10 \mathrm{~kg} \mathrm{ha}^{-1}$ on sowing and $60 \mathrm{~kg}$ $\mathrm{ha}^{-1}$ of $\mathrm{N}$ on cover.

The maize hybrid utilized on the first season period was $\mathrm{P} 2830 \mathrm{H}$, which has a super-early cycle. For the off-season the maize hybrid utilized was CD384Hx with early cycle, in which both materials are indicated for plantation in first and second season, in areas of Chapadão do Sul. The experimental plots were composed by five lines with $5 \mathrm{~m}$ of length, with spacing of $0,45 \mathrm{~m}$ between them and three seeds per meter, aiming at a density of 66.666 plants per hectare. 
For the inoculant preparation, the bacterial isolate MAY1 was grown by Dygs for 24 hours, under constant agitation of $100 \mathrm{rpm}$ at $30^{\circ} \mathrm{C}$. To verify the presence of contaminants, parts of $20 \mu \mathrm{L}$ of the cultivation were transferred and grown on a period of 3 to 5 days in $\mathrm{NFb}$ semi-solid environment, this one being semi-specific for Azospirillum spp. Afterwards, it was placed in solid potato environment for verification of the type of colony characteristic of Azospirillum spp.

The seed inoculations were conducted at the moment of sowing, in which the seeds were packed in plastic bags with volume of $300 \mathrm{~mL} \mathrm{ha}^{-1}$ of the commercial inoculant and agitated until its complete homogenization. It was made likewise the treatments containing the MAY1 isolate utilizing a part of 100 $\mathrm{mL} \mathrm{ha} \mathrm{h}^{-1}$. For the pulverization of the groove, it was utilized manual pump with flow of $180 \mathrm{~L} \mathrm{ha}^{-1}$, in which there was applied the same volume of inoculant directly on the seeds and afterwards the groove was closed. For the nitrogen containing treatments, there was applied $20 \mathrm{~kg} \mathrm{ha}^{-1}$ of $\mathrm{N}$ utilizing the urea as source of $\mathrm{N}(45 \%$ of $\mathrm{N})$ on the sowing moment.

The maize topdressing fertilization was conducted between V4 and V5 phenological state. To maize sowing in season, the topdressing fertilization on dosage of $180 \mathrm{~kg} \mathrm{ha}^{-1}$ of $\mathrm{N}$ occurred in December $16^{\text {th }}, 2014,25$ days after sow, while to the maize sowing off-season, on the fertilization dosage of $60 \mathrm{~kg}$ $\mathrm{ha}^{-1}$ of $\mathrm{N}$ occurred in March $27^{\text {th }}, 2015,28$ days after sow, both utilizing urea as source of $\mathrm{N}$ (45\% of N), manually applied on the soil surface, without incorporation.

During the season period, there was conducted only one application for the phytosanitary control of weed with products based on the active ingredients Atrazina 2,0 L ha ${ }^{-1}+$ Tembotriona 0,240 L ha-1, and for control of caterpillars there was utilized the Metomil 0,5 L ha ${ }^{-1}$ ingredient. For the off-season, there was conducted two applications, one identical to the season period and the other utilizing the products: Azoxitrobina+Ciproconazol 0,125 $\mathrm{L} \mathrm{ha}^{-1}+$ Mancozeb 1,5 $\mathrm{kg} \mathrm{ha}^{-1}+$ Flubendiamida 0,80 $\mathrm{L} \mathrm{ha}^{-1}$.

The following evaluations were conducted: number of grains per ear, total ear number, grain mass per ear, 100-grain mass, nitrogen level on the grains and productivity.

The harvest of the season-maize and of the off-season maize was conducted manually on April $20^{\text {th }}$ and July $10^{\text {th }}$ of 2015 , respectively, with five ears being randomly selected from the useful area for evaluation of the following variables: grain mass per ears, number of grains per ear and 100-grain mass. Also, there was done the counting of the number of ears produced on the useful area of each part.

The data of productivity were obtained by mechanic trail and the weighing of the estimated grain in $\mathrm{kg} \mathrm{ha}^{-1}$ with corrected humidity to $13 \%$. For the analysis of the total nitrogen level on the grains, there 
was separated a sample of grains from each part for realization of the milling, sulfuric digestion, distillation and titration (K-jeldahl), method adapted by Galvani e Gaertner (2006).

The data obtained were submitted to the variance analysis by $\mathrm{F}$ test and the means compared by the Tukey and Dunnet test, both at $5 \%$ of significance, utilizing the software SISVAR (FERREIRA, 2014).

\section{RESULTS AND DISCUSSION}

On the season period, the variable number of grains per ear did not presented difference between the evaluated treatments. For the number of grains per ear, the control presented lesser yield regarding all of the other treatments (Table 1).

Table 1. Number of grains per ear (NGE), number of total ears (NET) and grain mass per ear (MGE) during the season period, Chapadão do Sul, MS, 2014/15

\begin{tabular}{|c|c|c|c|c|c|c|}
\hline \multirow{3}{*}{ Treatments } & \multicolumn{2}{|c|}{$\operatorname{NGE}\left(n^{\circ}\right)$} & \multicolumn{2}{|c|}{$\operatorname{NET}\left(n^{0}\right)$} & \multicolumn{2}{|c|}{ MGE (g) } \\
\hline & \multicolumn{6}{|c|}{ BACTERIA } \\
\hline & $\begin{array}{c}\text { Azosp. } \\
\text { commercial }\end{array}$ & $\begin{array}{l}\text { Azosp. } \\
\text { MAY1 }\end{array}$ & $\begin{array}{c}\text { Azosp. } \\
\text { commercial }\end{array}$ & $\begin{array}{l}\text { Azosp. } \\
\text { MAY1 }\end{array}$ & $\begin{array}{c}\text { Azosp. } \\
\text { commercial }\end{array}$ & $\begin{array}{l}\text { Azosp. } \\
\text { MAY1 }\end{array}$ \\
\hline $\mathrm{No} N+$ Seed & $575^{\mathrm{ns}}(\mathrm{a})$ & $499^{\mathrm{ns}}(\mathrm{a})$ & $48148^{\text {ns }}$ (a) & $53333^{\text {ns }}$ (a) & 129 bA (b) & $144 b A(a)$ \\
\hline No $\mathrm{N}+$ Groove & $606^{\mathrm{ns}}(\mathrm{a})$ & $539^{\text {ns }}(a)$ & $44444^{\mathrm{ns}}(\mathrm{b})$ & $45926^{\mathrm{ns}}(\mathrm{b})$ & $167 \mathrm{aA}(\mathrm{a})$ & $136 \mathrm{bB}(\mathrm{b})$ \\
\hline $\begin{array}{l}\text { With } N+\text { Seed } \\
\text { With } N+\end{array}$ & $615^{\mathrm{ns}}(\mathrm{a})$ & $586^{\text {ns }}(\mathrm{a})$ & $45926^{\mathrm{ns}}(\mathrm{b})$ & $50370^{\text {ns }}(\mathrm{a})$ & 157 aA (a) & $146 \mathrm{bA}(\mathrm{a})$ \\
\hline Groove & $552^{\mathrm{ns}}(\mathrm{a})$ & $663^{\text {ns }}(a)$ & $57037^{\mathrm{ns}}(\mathrm{a})$ & $47407^{\mathrm{ns}}(\mathrm{b})$ & 132 bB (b) & $185 \mathrm{aA}(\mathrm{b})$ \\
\hline Control & 537(b) & 537(b) & $37037(b)$ & 37037(b) & 162(a) & 162(a) \\
\hline $\mathrm{CV}(\%)$ & \multicolumn{2}{|c|}{7,5} & \multicolumn{2}{|c|}{9,0} & \multicolumn{2}{|c|}{6,1} \\
\hline
\end{tabular}

Means followed by same lower cases in the columns and capital case on lines, do not differ by the Tukey test at 5\% of probability; ${ }^{\text {ns }}$ - non-significant; means followed by same letters between parenthesis on the column do not differ by the Dunnett test at $5 \%$ of probability; $\mathrm{CV}$ - coefficient of variation.

For total number of ears, the Abv5 + Abv6 strain use, result high inoculation values in seeds without $\mathrm{N}$ and groove application with $\mathrm{N}$. Those treatments result in average values $16.4 \%$ higher than the other treatments and $42.0 \%$ higher than the control. With the MAY1 strain use, the high values were observed in treatments with seeds inoculation, both for application of $\mathrm{N}$ and without application of $\mathrm{N}$. Those treatments result an average increase of $11.1 \%$ on the number of total ears when compare to the others treatments and e $40.0 \%$ higher than the control. For grain mass per ear, treatments did not result in the increasing averages when compared to control, but with the Abv5 + Abv6 strains use, the seed inoculation without $\mathrm{N}$ use and the groove application with $\mathrm{N}$, result average losses of $24.1 \%$ in the grain 
mass. With the MAY1 strain, the grain mass average losses was14.1 to all treatments, except in the bacteria groove application with $\mathrm{N}$.

The Abv5 + Abv6 strains groove application, without $\mathrm{N}$ increase $22.8 \%$ in the grain mass per ear, when compared to MAY1 strain. To bacteria groove application with N, the MAY1 strain provided gain of $40.1 \%$ in the grain mass per ear when compared to Abv5 + Abv6 strain use (Table 1).

For the off-season, the number of grains per ear, number of total ears and grain mass per ear presented non-significant results when compared to the treatments. Comparing it to the control, the only treatment that presented difference regarding the number of grains per ear was the one without nitrogen fertilization with inoculation of the strain MAY1 on the seed. This treatment provides average increase in the number of grains per ear of $17.3 \%$ compare to the others treatments and $28.1 \%$ compared to control (Table 2).

Table 2. Number of grains per ear (NGE), number of total ears (NET) and grain mass per ear (MGE) during the off-season period, Chapadão do Sul, MS, 2014/15

\begin{tabular}{|c|c|c|c|c|c|c|}
\hline \multirow{3}{*}{ Treatments } & \multicolumn{2}{|c|}{$\operatorname{NGE}\left(n^{\circ}\right)$} & \multicolumn{2}{|c|}{$\operatorname{NET}\left(n^{0}\right)$} & \multicolumn{2}{|c|}{ MGE (g) } \\
\hline & \multicolumn{6}{|c|}{ BACTERIA } \\
\hline & $\begin{array}{c}\text { Azosp. } \\
\text { commercial }\end{array}$ & $\begin{array}{l}\text { Azosp. } \\
\text { MAY1 }\end{array}$ & $\begin{array}{c}\text { Azosp. } \\
\text { commercial }\end{array}$ & $\begin{array}{l}\text { Azosp. } \\
\text { MAY1 }\end{array}$ & $\begin{array}{c}\text { Azosp. } \\
\text { commercial }\end{array}$ & $\begin{array}{l}\text { Azosp. } \\
\text { MAY1 }\end{array}$ \\
\hline No N + Seed & $536^{\mathrm{ns}}(\mathrm{b})$ & $634^{\mathrm{ns}}(\mathrm{a})$ & $55556^{\mathrm{ns}(\mathrm{ns})}$ & $57778^{\mathrm{ns}(\mathrm{ns})}$ & $112^{\mathrm{ns}(\mathrm{ns})}$ & $89^{\mathrm{ns}(\mathrm{ns})}$ \\
\hline No $\mathrm{N}+$ Groove & $520^{\mathrm{ns}}(\mathrm{b})$ & $549^{\mathrm{ns}}(\mathrm{b})$ & $55556^{\mathrm{ns}(\mathrm{ns})}$ & $56296^{\mathrm{ns}(\mathrm{ns})}$ & $101^{\mathrm{ns}(\mathrm{ns})}$ & $78^{\mathrm{ns}(\mathrm{ns})}$ \\
\hline $\begin{array}{l}\text { With } N+\text { Seed } \\
\text { With } N+\end{array}$ & $537^{\mathrm{ns}}(\mathrm{b})$ & $497^{\mathrm{ns}}(\mathrm{b})$ & $60741^{\mathrm{ns}(\mathrm{ns})}$ & $57037^{\mathrm{ns}(\mathrm{ns})}$ & $115^{\mathrm{ns}(\mathrm{ns})}$ & $97^{\mathrm{ns}(\mathrm{ns})}$ \\
\hline Groove & $522^{\mathrm{ns}}(\mathrm{b})$ & $575^{\mathrm{ns}}(\mathrm{b})$ & $54815^{\mathrm{ns}(\mathrm{ns})}$ & $50370^{\mathrm{ns}(\mathrm{ns})}$ & $89^{\text {ns (ns) }}$ & $86^{\mathrm{ns}(\mathrm{ns})}$ \\
\hline Control & 495(b) & 495(b) & $57037^{\text {(ns) }}$ & $57037^{(\mathrm{ns})}$ & $104^{\text {ns (ns) }}$ & $104^{\mathrm{ns}(\mathrm{ns})}$ \\
\hline $\mathrm{CV}(\%)$ & \multicolumn{2}{|c|}{8,9} & \multicolumn{2}{|c|}{8,4} & \multicolumn{2}{|c|}{9,3} \\
\hline
\end{tabular}

Means followed by the same lower cases on the columns and capital case on lines, do not differ by Tukey test at 5\% of probability; ${ }^{\text {ns }}$ - non-significant; means followed by same letters between parenthesis on the column do not differ by Dunnett test at $5 \%$ of probability of $\mathrm{CV}$ - coefficient of variation.

At the beginning of the studies with Azospirillum, it was believed that the positive results obtained in works conducted were essentially derived from the biological fixation of the atmospheric nitrogen (DOBBELAERE et al., 2001). However, posterior studies related that the positive results provided by these microorganisms were also derived from the morphological and physiological alterations on the plants roots and plants with inoculation, which resulted in a higher absorption of water and nutrients (SPAEPEN; VANDERLEYDEN, 2011; HUNGRIA et al., 2016; MARTINS et al., 2017). 
The high level of organic matter present on the soil $\left(29.5 \mathrm{~g} \mathrm{dm}^{-3}\right)$ may have interfered on the observed results, providing the necessary nutrients for the expressivity of the results, improving its characteristics of aeration, better retention and hydrological storage, besides the physicochemical properties of the soil, providing a higher cation exchange capacity of the soil (CeEC) and also contributing for the survival of the microbiota present on the soil (FIGUEIREDO et al, 2008). This is a soil inherent condition founded in the commercial planting. It noted for number of grains per ear, number of total ears and grain mass per ear variables, discrepancy results, mainly in season. According to Bartchechen et al. (2010) the results discrepancy obtained with Azospirillum in the maize crop, which may vary according to the hybrid used, with climatic conditions and methodology used in the research. For the productivity on the season period, the treatment with nitrogen fertilization inoculated with the strain MAY1 on the seed presented a higher production of grains. For the 100-grain mass and nitrogen level on the grains, the treatments present non-significant results (Table 3).

Table 3. Productivity of the maize (PROD), 100-grain mass (MCG) and nitrogen level on grains (TNG) during the season period, Chapadão do Sul, MS, 2014/15

\begin{tabular}{|c|c|c|c|c|c|c|}
\hline \multirow{3}{*}{ Treatments } & \multicolumn{2}{|c|}{$\operatorname{MCG}\left(\mathrm{g}^{0}\right)$} & \multicolumn{2}{|c|}{ TNG $(\%)$} & \multicolumn{2}{|c|}{ PROD $\left(\mathrm{kg} \mathrm{ha}^{-1}\right)$} \\
\hline & \multicolumn{6}{|c|}{ BACTERIA } \\
\hline & $\begin{array}{c}\text { Azosp. } \\
\text { commercial }\end{array}$ & $\begin{array}{l}\text { Azosp. } \\
\text { MAY1 }\end{array}$ & $\begin{array}{c}\text { Azosp. } \\
\text { commercial }\end{array}$ & $\begin{array}{l}\text { Azosp. } \\
\text { MAY1 }\end{array}$ & $\begin{array}{c}\text { Azosp. } \\
\text { commercial }\end{array}$ & $\begin{array}{l}\text { Azosp. } \\
\text { MAY1 }\end{array}$ \\
\hline No N + Seed & $30.26^{\mathrm{ns}(\mathrm{ns})}$ & $29.77^{\mathrm{ns}(\mathrm{ns})}$ & $2.46^{\mathrm{ns}(\mathrm{ns})}$ & $2.62^{\mathrm{ns}(\mathrm{ns})}$ & $5155 \mathrm{aA}(\mathrm{a})$ & $5307 \mathrm{bA}(\mathrm{a})$ \\
\hline No N + Groove & $30.01^{\mathrm{ns}}\left({ }^{\mathrm{ns}}\right)$ & $28.46^{\mathrm{ns}(\mathrm{ns})}$ & $2.52^{\mathrm{ns}(\mathrm{ns})}$ & $2.37^{\mathrm{ns}(\mathrm{ns})}$ & $5107 \mathrm{aA}(\mathrm{a})$ & $5267 \mathrm{bA}(\mathrm{a})$ \\
\hline With $N+$ Seed & $30.56^{\text {ns (ns) }}$ & $29.77^{\mathrm{ns}(\mathrm{ns})}$ & $2.49^{\mathrm{ns}(\mathrm{ns})}$ & $2.62^{\mathrm{ns}(\mathrm{ns})}$ & $6063 \mathrm{aB}(\mathrm{a})$ & $6819 \mathrm{aA}(\mathrm{b})$ \\
\hline With $\mathrm{N}+$ Groove & 30.52 ns (ns) & $32.94^{\mathrm{ns}(\mathrm{ns})}$ & $2.76^{\mathrm{ns}(\mathrm{ns})}$ & $2.72^{\mathrm{ns}(\mathrm{ns})}$ & $6404 \mathrm{aA}(\mathrm{a})$ & $5815 \mathrm{bA}(\mathrm{a})$ \\
\hline Control & $3.93^{(\mathrm{ns})}$ & $3.93^{(\mathrm{ns})}$ & $2.57^{\text {(ns) }}$ & $2.57^{(\mathrm{ns})}$ & 5063(a) & 5063(a) \\
\hline $\mathrm{CV}(\%)$ & \multicolumn{2}{|c|}{5.37} & \multicolumn{2}{|c|}{3.52} & \multicolumn{2}{|c|}{10.47} \\
\hline
\end{tabular}

Means followed by same lower case on the columns and capital case on lines, do not differ by the Tukey test at 5\% of probability; ${ }^{\text {ns }}$ - non-significant; means followed by same letters between parenthesis on the column do not differ by the Dunnett test at $5 \%$ of probability CV - coefficient of variation.

On the off-season, when analyzing the productivity of the treatments regarding the control, the treatment without nitrogen fertilization with application of the strain MAY1 on the groove present inferior result to it, besides presenting difference from the other treatments. For the nitrogen level on grains, the control did not differ of the treatments without nitrogen with pulverization both of the strains Abv5 + Abv6 and MAY1 on the groove and of the treatment with nitrogen fertilization with pulverization of the strain Abv5 + Abv6 on the groove. The other analyzed variables presented non-significant results (Table 4). 
Table 4. Productivity of the maize (PROD), 100-grain mass (MCG) and nitrogen level on the grains (TNG) during the off-season period, Chapadão do Sul, MS, 2014/15

\begin{tabular}{|c|c|c|c|c|c|c|}
\hline \multirow{3}{*}{ Treatments } & \multicolumn{2}{|c|}{$\operatorname{MCG}\left(\mathrm{g}^{\mathrm{o}}\right)$} & \multicolumn{2}{|c|}{ TNG (\%) } & \multicolumn{2}{|c|}{ PROD $\left(\mathrm{kg} \mathrm{ha}^{-1}\right)$} \\
\hline & \multicolumn{6}{|c|}{ BACTERIA } \\
\hline & $\begin{array}{c}\text { Azosp. } \\
\text { commercial }\end{array}$ & $\begin{array}{l}\text { Azosp. } \\
\text { MAY1 }\end{array}$ & $\begin{array}{c}\text { Azosp. } \\
\text { commercial }\end{array}$ & $\begin{array}{l}\text { Azosp. } \\
\text { MAY1 }\end{array}$ & $\begin{array}{c}\text { Azosp } \\
\text { commercial }\end{array}$ & $\begin{array}{l}\text { Azosp. } \\
\text { MAY1 }\end{array}$ \\
\hline No N + Seed & $21.91^{\mathrm{ns}(\mathrm{ns})}$ & $19.87^{\mathrm{ns}(\mathrm{ns})}$ & $2.84^{\mathrm{ns}}(\mathrm{b})$ & $2.76^{\mathrm{ns}}(\mathrm{b})$ & $4193^{\mathrm{ns}}(\mathrm{a})$ & $2459^{\mathrm{ns}}$ (a) \\
\hline Groove & $21.76^{\mathrm{ns}(\mathrm{ns})}$ & $18.68^{\mathrm{ns}(\mathrm{ns})}$ & $2.52^{\mathrm{ns}}$ (a) & $2.53^{\mathrm{ns}}(\mathrm{a})$ & $3504^{\mathrm{ns}}(\mathrm{a})$ & $2011^{\mathrm{ns}}(\mathrm{b})$ \\
\hline $\begin{array}{l}\text { With } N+\text { Seed } \\
\text { With } N+\end{array}$ & $22.13^{\mathrm{ns}(\mathrm{ns})}$ & $18.94^{\text {ns (ns) }}$ & $2.83^{\mathrm{ns}}(\mathrm{b})$ & $2.70^{\mathrm{ns}}(\mathrm{b})$ & $3800^{\mathrm{ns}}$ (a) & $3804^{\mathrm{ns}}$ (a) \\
\hline Groove & $21.50^{\mathrm{ns}(\mathrm{ns})}$ & $22.10^{\mathrm{ns}(\mathrm{ns})}$ & $2.64^{\mathrm{ns}}(\mathrm{a})$ & $2.69^{\mathrm{ns}}(\mathrm{b})$ & $3563^{\mathrm{ns}}(\mathrm{a})$ & $3563^{\mathrm{ns}}(\mathrm{a})$ \\
\hline Control & $19.10^{(\mathrm{ns})}$ & $19.10^{(\mathrm{ns})}$ & $2.27(\mathrm{a})$ & $2.27(\mathrm{a})$ & $3356(a)$ & $3356(\mathrm{a})$ \\
\hline CV (\%) & 8. & & 6.7 & & 12 & \\
\hline
\end{tabular}

Means followed by same lower cases on the columns and capital case on lines, do not differ by the Tukey test at 5\% of probability; ${ }^{\mathrm{ns}}$ - non-significant; means followed by same letter between parenthesis on the column do not differ by the Dunnett test at $5 \%$ of probability $\mathrm{CV}$ - coefficient of variation.

There was an increase on the productivity when the treatments were compared with presence or absence of nitrogen fertilization, both being associated with Azospirillum brasilense. For the season period, the increase was of $1066 \mathrm{~kg}$ ha, with gain equivalent to $20 \%$ on the production with the use of nitrogen fertilization. On the off-season, the treatments presented increase of $640 \mathrm{~kg}$ ha, which represents $21 \%$ of the rise on the productivity with the use of fertilization.

In a common way, the use of Azospirillum brasilense associated or not with the nitrogen fertilization presented results of good productivity. Even without the utilization of the nitrogen fertilization, the treatments with the strains Abv5 + Abv6 could reach good production regarding the treatments with use of nitrogen fertilization.

Regarding the inoculation system seed and groove, the results showed similarity with each other, indicating that the other Azospirillum brasilense application methods different from traditional seed inoculation can be used. Fukami et al (2016), got the same results when studying the soil surface and foliar application of this bacteria.

According to Kappes et al. (2014), the 100-grain mass expression is a characteristic that may be influenced by the genotype, by the nutrient availability and by the climatic conditions during the grain filling stage.

The nitrogen levels on inoculated plants with action combined with the diazotrophic bacteria are also related by other authors, which can be consequence of the growth promotion mechanisms, which 
can improve the capacity of the plants of absorbing nitrogen and fostering the productivity growth (DOBBELAERE et al., 2001). The results with the use of the strain MAY1 corroborates with this affirmation once it presents, according to Souza et al. (2017), high phytormonium AIA production and this hormone, according to Spaepen e Vanderleyden (2015); Martins et al. (2017) can provide an increase of the plant root system, which will explore greater soil area favoring the absorption of water and nutrients present in the midst, helping in the good development of the plant and reflecting positively on grain yield. Still, according to Martins et al. (2017), the growth-promoting bacteria can improve the conversion of nitrogen fertilizer, which is an expensive input, in grain production, reducing environmental problems resulting from the inefficient use of synthetic nitrogen fertilizer by maize.

Some authors relate positive results with the use of Azospirillum like Cavallet et al. (2000), without strain identification and Hungria et al. (2010), using Abv1, Abv2, Abv4, Abv5, Abv6, Abv7 e Abv8 strain, who obtained gains of productivity on the order of $17 \%$ and $9 \%$ respectively, with the use of the bacteria Azospirillum spp. in maize associated with fertilization. Similar results were also found by Kappes et al. (2011) and Braccini et al. (2012), who observed increase on the productivity with the treatments with inoculation.

The results preset on the literature of the effects of the use of Azospirillum regarding the agronomic performance on maize culture still fairly variable (BARTCHECHEN et al., 2010). According to Duarte et al. (2012), the effects of the nitrogen fertilization with the use combined of the inoculation with Azospirillum on the nutrition and productivity on the maize culture is related to the utilized cultivar, besides the current soil and climate conditions.

This experiment, sought an alternative way of using the A. brasilense, with the groove application, process that avoids the direct contact of the bacteria with the chemicals used in the seeds treatment for a longer time, however, according to Bashan e Holguin (1995); Bartchechen et al (2010), the survival on soil of the inoculated bacteria is essential for the success of the inoculation, varying according to the type of soil, climate and plant conditions. Therefore, according with Roesch et al. (2007) the isolation of microorganisms and the selection of bacterial characteristics which provides beneficial effects on plants, besides competitive strains are important steps for optimizing yield raise on cultures and enhance the sustainability of the ecosystem.

Also, in this experiment, the MAY1 strain use who show high indo acetic production (SOUZA et al., 2017) important in the search for productive increments in the maize crop, this occurs because according to Hungria (2011), for an interaction between plant and bacteria happen, is indispensable the 
use of selected strains of $A$. brasilense in order to compose the inoculant, for the occurrence of positive effect on the agronomic variables on maize culture. In a work conducted by Santos et al. (2014) it was possible to realize the isolation of 30 strains present in plants of maize, in which two strains presented a good production of indo acetic acid and four strains with good production of activity of nitrogenase, showing itself with high potential for use in inoculations on maize plants.

\section{CONCLUSIONS}

The use of inoculants with the strains Abv5 + Abv6 and MAY1, inoculated on the seeds and on the groove on the absence of nitrogen fertilization increases the grain mass per ear in season maize culture.

The MAY1 strain seed inoculation with $\mathrm{N}$ use provided productivity increase in the maize grain season.

Both Abv5 + Abv6 strain did not result in increased maize grain yield. In addition, the use of any strain studied did not result in increased of maize grain yield when submitted to groove application.

For maize off-season, only the number of grains per ear was benefited with The MAY1 strain seed inoculation without $\mathrm{N}$ use.

\section{REFERENCES}

ARAÚJO, R.M.; ARAÚJO, A.S.F.; NUNES, L.A.P.L.; FIGUEIREDO, M.V.B. 2014. Resposta do milho verde à inoculação com Azospirillum brasilense e níveis de nitrogênio. Ciência Rural, Santa Maria, v. 44, n. 9, p. 1556-1560.

BARTCHECHEN, A.; FIORI, C. C. L.; WATANABE, S. H.; GUARIDO, R. C. 2010. Efeito da inoculação de Azospirillum brasilense na produtividade da cultura do milho (Zea mays L.). Campo Digit@l, Campo Mourão, v. 5, n. 1, p. 56-59.

BASHAN, Y.; HOLGUIN, G. 1995. Inter-root movement of Azospirillum brasilense and subsequent root colonization of crop and weed seedlings growing in soil. Microbial Ecology, New York, v. 29, p. 269-281.

BRACCINI, A.L.; DAN, L.G.M.; PICCININ, G.G.; ALBRECHT, L.P.; BARBOSA, M.C.; ORTIZ, A.H.T. 2012. Seed inoculation with Azospirillum brasilense, associated with the use of bioregulators in maize. Revista Caatinga, Mossoró, v. 25, n. 2, p.58-64.

CASSÁN, F.; SGROY, V.; PERRIG, D.; MASCIARELli, O. Y LUNA, V. 2008. Producción de fitohormonas por Azospirillum sp. aspectos fisiológicos y tecnológicos de la promoción del crecimiento vegetal. In: CASSÁN, F.; SALAMONE, I. G. (Ed.). Azospirillum sp., cell physiology, plant interactions and agronomic research in Argentina. Asociación Argentina de Microbiología, Buenos Aires, p. 61-78.

CAVAlLET, L.E.; PESSOA, A.C.S.; HELMICH, J.J.; HELMICH, P.R.; OST, C. F. 2000. Produtividade do milho em resposta à aplicação de nitrogênio e inoculação das sementes com 
Azospirillum spp. Revista Brasileira de Engenharia Agrícola e Ambiental, Campina Grande, v. 4, n. 1, p. 129-132.

CONAB, Companhia Nacional De Abastecimento, 2018. Acompanhamento de safra brasileira: grãos. Nono levantamento, junho de 2018. Brasília-DF, 178 p.

CRUZ, J.C.; PEREIRA FILHO, I.A.; DUARTE, A.P. 2010. Milho Safrinha. Brasília: Ageitec.

Embrapa. Available at:

<http://www.agencia.cnptia.embrapa.br/gestor/milho/arvore/CONT000fya0krse02wx5ok0pvo4k3 mp7ztkf.html>. Access in January 10 Jan, 2016.

CUNHA, F. F.; MAGAlHÃES, F. F.; CASTRO, M. A. 2013. Métodos para estimativa da evapotranspiração de referência para Chapadão do Sul, MS. Engenharia na Agricultura, Viçosa, v. 21, n. 1, p. 159-172.

DOBBELAERE, S.; CROONENBORGHS, A.; THYS, A.; PTACEK, D.; VANDERLEYDEN, J.; DUTTO, P.; LABANDERA-GONZALEZ, C.; CABALLE ROMELLADO, J.; AGUIRRE, J. F.; KAPULNIK, Y.; BRENER, S.; BURDMAN, S.; KADOURI, D.; SARIG, S.; OKON, Y. 2001. Responses of agronomically important crops to inoculation with Azospirillum. Australian Journal of Plant and Physiology, Victoria, v. 28, n. 9, p. 871- 879.

DÖBEREINER, J. 1990. Avanços recentes na pesquisa em fixação biológica de nitrogênio no Brasil. Estudos Avançados, São Paulo, v. 4, n. 8, p. 144-152.

DUARTE, A.P.; PIEDADE, R.C.; MARTINS, V.C.; CANTARELLA, H.; BARROS, V.L.N. 2012. Resposta de cultivares de milho ao nitrogênio em cobertura e à inoculação com Azospirillum. In: Congresso Nacional de Milho e Sorgo, 29, Águas de Lindoia. p. 1786-92.

FARINELLI, R.; LEMOS, L.B. Nitrogênio em cobertura na cultura do milho em preparo convencional e plantio direto consolidados. Pesquisa Agropecuária Tropical, v. 42, n.1, p.63-70, 2012. Available at: www.agro.ufg.br/pat. Access in January 10, 2016.

FERREIRA, D. F. Sisvar: a Guide for its Bootstrap procedures in multiple comparisons. 2014. Ciência e Agrotecnologia, Lavras, v. 38, n. 2, p. 109-112.

FIGUEIREDO, C.C.; RAMOS, M.L; TOSTES, R. 2008. Propriedades físicas e matéria orgânica de um Latossolo vermelho sob sistemas de manejo e cerrado nativo. Bioscience Journal. Uberlândia, v. 24, n. 3, p. 24-30.

FIORI, C.C.L.; BARTCHECHEN, A.; WATANABI, S.H; GUARIDO, R.C. 2010. Efeito da inoculação de Azospirillum brasiliense na produtividade da cultura do milho (Zea mays L.). Revista Campo Digit@1, Campo Mourão, v. 5, p. 56-59.

FUKAMI, J.; NOGUEIRA, M.A.; ARAUJO, R.S.; HUNGRIA, M. 2016. Accessing inoculation methods of maize and wheat with Azospirillum brasilense, AMB Express, Berlim, v. 6, n. 3.

GALVANI, F.; GAERTNER, E. 2006 - Adequação da metodologia Kjeldahl para determinação de nitrogênio total e proteína bruta. Corumbá: Embrapa Pantanal. 9 p. (Circular Técnica, 63).

HERRERA, J.M.; RUBIO, G.; LEVY, L.; DELGADO, J.A.; LUCHO-CONSTANTINO, C.A.; ISLASVALDEZ, S.; PELLET, D. 2016. Emerging and established technologies to increase nitrogen use efficiency of cereals. Agronomy, Basel, v. 6, n. 2, p. 25. doi:10.3390/agronomy6020025.

HUNGRIA, M. (2011) - Inoculação com Azospirillum brasilense: inovação em rendimento a baixo custo. Londrina: Embrapa Soja, 37 p. (Documentos, 325).

HUNGRIA, M.; CAMPOS, R.J.; SOUZA, E.M.; PEDROSA, F.O. 2010. Inoculation with selected strains of Azospirillum brasilense and A. lipoferum improves yields of maize and wheat in Brazil. Plant Soil, Dordrecht, v. 331, p. 413-25.

HUNGRIA, M.; NOGUEIRA, M.A.; ARAUJO, R.S. 2016. Inoculation of Brachiaria spp with the plant growth-promoting bacterium Azospirillum brasilense: an environment-friendly component in the 
reclamation of degraded pastures in the tropics. Agriculture Ecosystems Environment, Amsterdam, v. 221, p. 125-131. doi :10.1016 / j.agee.2016.01.024.

KAPPES, C.; ANDRADE, J.A.C.; ARF, O.; OLIVEIRA, A.C.; ARF, M.V.; FERREIRA, J.P. 2011. Desempenho de híbridos de milho em diferentes arranjos espaciais de plantas. Bragantia, Campinas, v. 70, n. 2, p. 334-343.

KAPPES, C.; ARF, O.; DAL BEM, E.A.; PORTUGAL, J.R.; GONZAGA, A.R. 2014. Manejo do nitrogênio em cobertura na cultura do milho em sistema plantio direto. Revista Brasileira de Milho e Sorgo, Sete Lagoas, v. 13, n. 2, p. 201-217.

MARTINS, M.R.; JANTALIA, C.P.; POLIDORO, J.C.; BATISTA, J.N.; ALVES, B.J.R.; BODDEY, R.M.; URQUIAGA, S. 2015. Nitrous oxide and ammonia emissions from $\mathrm{N}$ fertilization of maize crop under no-till in a Cerrado soil. Soil \& Tillage Research, Amsterdam, v.151, p.75-81. doi:10.1016/j. still.2015.03.004.

MARTINS, M.R.; JANTALIA, C.P.; REIS, V.M.; DOWICH, I.; POLIDORO, J.C.; ALVES, B.J.R.; BODDEY, R.M.; URQUIAGA, S. 2017. Impacto f plant growth-promoting bacteria on grain yeld, protein content, and urea-15 N recovery by maize in a Cerrado Oxisol. Plant Soil, Dordrecht, v. 422, p. 239-250. doi: 10.1007/s11104-017-3193-1.

OWEN, D.; WILLIAMS, A.P.; GRIFFITH, G.W.; WITHERS, P.J.A. 2015. Use of commercial bioinoculants to increase agricultural production through improved phosphrous acquisition. Applied Soil Ecology, Amsterdam, v. 86, p.41-54. doi:10.1016/j.apsoil.2014.09.012

QUADROS, P.D.; ROESCH, L.F.W; SILVA, P.R.F.; VIEIRA, V.M.; ROEHRS, D.D.; CAMARGO, F.A.O. 2014. Desempenho agronômico a campo de híbridos de milho inoculados com Azospirillum. Revista Ceres, Viçosa, v. 61, n. 2, p. 209-218.

ROESCH, L.F.W.; QUADROS, P.D.Q.; CAMARGO, F.A.O.; TRIPLETT, E.W. 2007. Screening of diazotrophic bacteria Azospirillum spp. for nitrogen fixation and auxin production in multiple field sites in southern Brazil. World Journal of Microbiology and Biotechnology, Dordrecht, v. 23, p. 1377-1383.

SAIKIA, S. P.; JAIN, V. 2007. Biological nitrogen fixation with non-legumes: an achievable Target or a dogma? Current Science. Bangalore. v. 92, n. 3, p. 317-322.

SANTOS, H. G.; JACOMINE, P. K. T.; ANJOS, L. H. C.; OLIVEIRA, V. A.; LUMBRERAS, J. F.; COElHO, M. R.; AlMEIDA, J. A. de; CUNHA, T. J. F.; OliVEIRA, J. B. 2013. Sistema brasileiro de classificação de solos. $3^{\mathrm{a}}$ ed. Brasília: Embrapa, 353p.

SANTOS, J.S.; VIANA, T.O.; JESUS, C.M., BALDANI, V.L.D.; FERREIRA, J.S. 2014. Inoculation and isolation of plant growth-promoting bacteria in maize grown in Vitória da Conquista, Bahia, Brazil. Revista Brasileira de Ciência do Solo, Viçosa, v. 39, p. 78-85.

SOUSA, D.M.G.; LOBATO, E., eds. 2004. Cerrado: Correção do solo e adubação. Planaltina, Embrapa Cerrados, 416p.

SOUZA, M.S.T.; BAURA, V.A.; SANTOS, S.A.; FERNADES-JUNIOR, P.I.; REIS JUNIOR, F.B.; MARQUES, M.R.; PAGGI, G.M.; BRASIL, M.S. 2017. Azospirillum spp. from native forage grasses in Brazilian Pantanal floodplain: biodiversity and plant growth promotion potential. World Journal of Microbiology and Biotechnology, Dordrecht, p. 33-81. doi:10.1007/s11274-017-22514.

SPAEPEN, S.; VANDERLEYDEN, J. 2011. Auxin and plant-microbe interactions. In: MARK, E; WEIJERS, D; LEYSER, O; LJUNG, K (eds). Cold Spring Harbor Perspectives in Biololgy. Cold Spring Harbor Laboratory Press. doi:10.1101/cshperspect.a001438. 
SPAEPEN, S.; VANDERLEYDEN, J. 2015. Auxin signaling in Azospirillum brasilense: a proteome analysis. In: BRUIJN, F.J. (ed). Biological Nitrogen Fixation. John Wiley \& Sons Inc, Hoboken. doi:10.1002/9781119053095.ch91.

USDA - National Agriculture Statistics Service. Agricultural Statistics. Washington: Government Printing Office. 2017. 512 p. 